\title{
Assimilating Socialist Core Values Education into College Ideological and Political Theory Course \\ Bo Cheng
}

\author{
School of Marxism Studies, Qujing Normal University, Qujing, China
}

916703339@qq.com

Keywords: Socialist core value system; Ideological and political theory course; Assimilating

\begin{abstract}
Socialist core value system is our Communist party's theoretical innovation and great achievement. Ideological and political theory course is the main channel and position of Ideological and political education of college students, their internal consistency requires the assimilating socialist core value system of education into ideological and political theory courses, which improves comprehensive quality of university students, as well as their healthy growth.
\end{abstract}

\section{Introduction}

At Communist party's the sixth Plenary Session of the 16th CPC Central Committee, proposition of socialist core value system construction was first proposed, The party's 17th further puts forward the socialist core value system into the whole process of national education and spiritual civilization construction, sixth Plenary Session of the 17th CPC Central Committee once again stressed that the socialist core value system is the soul of a country and essence of socialist advanced culture, which determines the direction of development of socialism with China characteristics[1]. We should advocate a prosperous, strong, democratic, civilized and harmonious society, advocating freedom, equality, justice and the rule of law. We should advocate patriotism, dedication, integrity and friendship, and actively cultivate and practice the socialist core values.

Universities are an important place for cultural construction and personnel training, shouldering the important task of cultural heritage, cultural development and cultural innovation, also it's an important position of the construction of the socialist core value system $[2,3]$. The ideological and political theory course is the main channel and the main position of the ideological and political education of college students, in the ideological and political theory course in the education of socialist core value system is the inevitable requirement to strengthen the ideological and political education.

\section{Socialist Core Values are the Basic Guide for the Contemporary College Students to Establish the Correct Ideals and Beliefs}

College Students' Characteristic. College students are full of patriotic enthusiasm. They have a strong cohesion, centripetal force and charisma of reform and innovation. In the trend of historical development, they always play the role of pioneer and bridge. However, with the profound changes in China's economic system reform, social structure, profound adjustment of benefit structure, together with the negative effect of market economy and global multicultural values, the value choice and cultural identity of college students show the variability and diversity [4, 5]. During college life, college students are in great need of new ideas and new knowledge, but the ability to distinguish right from wrong, enter the new liberalism, democratic socialism, historical nihilism and other social trends, impact and pollution with the spirit of students. Some of them are political belief confusion, fuzzy ideals and beliefs and values distorted, weak sense of integrity, lack of social responsibility, dilute the spirit of arduous struggle, the concept of unity and coordination is poor, poor psychological qualities, action and lax and other issues, and lack of faith, lofty ideal, clear objectives. All these will affect the growth of College students.

College students are valuable human resources, is the hope of the nation, the future of the motherland. They are the backbone of the construction of socialism with Chinese characteristics in 
the future. They are entrusted with the historical task of building a well-off society in an all-round way and realizing the great rejuvenation of the Chinese nation. The political and ideological quality of college students are directly related to the future and destiny of the party and the state [6].

Socialist Core Values. The socialist core value system is the essence of socialist advanced culture, it reflects the nature and direction of socialist advanced culture, the ideological and Political Theory Course Teaching of higher education and the construction of socialist core value system have a high degree of consistency in the basic function, fully embodies the socialist core value system [7,8]. College Ideological and political theory course should integrate into the socialist core value system education curriculum content, through the ideological and political theory course unique function, the socialist core value system plays a leading role in the ideological and political education in universities.

College Ideological and political theory course is planned at 2006, and content system of Ideological and political theory course mainly includes three aspects: one is based on the basic principle of the Marx doctrine as the basis, and to preliminarily grasp and use the basic position, viewpoint and method to understand the Marx doctrine as the focus of the course and transform the world; the other one is in the Marx doctrine Chinese theory results as the focus of the course; last one is the training course, for the great rejuvenation of the Chinese nation's patriotism and the common ideal of socialism, promote the ideological and moral quality is the focus of the course. The content of the curriculum and the content of the socialist core value system have high degree of adaptability, which provides a clear requirement for the integration of the socialist core value system education in the ideological and political theory teaching in Colleges and universities. Especially for the spirit of the party's eighteen, the Ministry of Education issued "the spirit of the eighteen teaching suggestions" of Ideological and political theory course to implement the party's five courses, how to infiltrate the socialist core value system for specific requirements [9, 10]. Further clarify the whole process of the socialist core value system into the ideological and political theory teaching.

The Course Basic Principle. The course basic principle of the Marx doctrine involves Marx doctrine, the scientific content and spirit, which enable students to grasp the Marx doctrine, recognize the basic rules of the development of human society, learn to use Marx's world outlook and methodology of understanding problems, analyze and solve problems, improve the ability of students to distinguish between right and wrong. The course Mao Zedong thought and theoretical system of socialism China characteristics is mainly the theory China of the Marx doctrine as a whole system of teaching, help students understand why Marx's Chinese, understanding of the Marx doctrine and the Chinese body combining the fruit of the great significance of the socialist theory system of Mao Zedong thought and Chinese characteristics in guiding China revolution and construction. The course Outline of modern Chinese history has function of education from the perspective of history of modern Chinese history. The course of Ideological and moral cultivation and legal basis is mainly to carry out socialist moral education and legal education for college students. The course Situation and policy mainly involves today's hot international and domestic problems, the party and the country's fundamental policy timely publicity to explain, and it's an important way to preach the socialist core value system.

From the logical structure, the ideological and political theory courses in Colleges and universities is the core of the socialist core value system as the main line throughout the curriculum system, is the embodiment of the socialist core value system. In the course of Ideological and political theory is an organic whole, with the socialist core value system should stand in the height of the whole, the overall permeability, it can strengthen the function of Ideological and political education of College students.

\section{The Construction of the Socialist Core Value System Requirements Puts Forward New Tasks for Ideological and Political Theory Course Teaching}

The ideological and political theory course belongs to curriculum theory, compared with other theoretical and ideological education channels, it's the most stable, the most systematic and 
standardized way of education, from the form of the socialist core value system into college education provides a good carrier.

Improving Comprehensive Quality of the Ideological and Political Theory Teachers. Teachers are the propagandist and executor of the party's policy theory. The whole process of the socialist core value system education into the ideological and political theory teaching, first is teachers' self-learning, self-education, spirit of comprehensive and accurate grasp of the socialist core value system, based on the teaching material content, combined with the national situation and the party situation, the situation of College Students' ideological and practical, organic integration, focus, difficulties. The teachers of the ideological and political theory courses in Colleges and universities should also make students personally, set an example, dare to adhere to justice and conscience, stand firm, firmly adhere to the socialist core value system of education, do not compromise, do not evade the issue, really become the ideological and political education concept and guide.

Assimilating Socialist Core Values into the Ideological and Political Courses Requires the Combination of Theory and Practical Teaching. College teachers must realize the organic combination of classroom teaching and practical teaching of the two links. The ideological and political theory course is the only form of education in the ideological and theoretical education in Colleges and universities, which is the only way to carry out the system of Marx's theory and ideological and moral education. Therefore, we must improve the ideological and political theory classroom control; give full play to the effectiveness of classroom teaching. Assimilating the socialist core value system into course can make students pay attention to the social reality, make students realize the importance of the socialist core value system for personal and social development, so as to enhance the consciousness of the establishment of the socialist core value system. Of course, the socialist core value system is the embodiments of socialist ideologies, which requires in addition to integration of external through classroom teaching, but also with the social reality closely, organize the implementation of various beneficial social activities, such as knowledge contest, speech contest, social investigation, visits, community services, intellectual poverty, and public welfare activities and so on. Complete the requirements of social practice of College Students under the guidance of teachers and practice report, in order to consolidate and deepen the teaching effect.

Adhering to Improve Comprehensive Quality of College Students as the Goal of Teaching Reform and Assessment Methods. The assessment of Ideological and political theory courses in Colleges and universities has always been the key and difficult issues in the reform. At present most of the assessment methods is nothing more than two: one is the mechanical test and formulistic, only pay attention to the basic knowledge, the concept of assessment, to cope with the past rote, can't really solve the ideological problems of college students; the other is a simple, open book, take the form of a question. The Internet, students copy the answer before, not really assess the ability of College students. The reform and innovation of evaluation methods, is to take the teaching goal as the standard, scientific and rational design of assessment content, assessment using a variety of forms, such as the basic theory of combination of knowledge and social practice, combined with the book with closed book, with the final exam with the usual examination, examination on college students use into the ideological and political theory of socialist core value the system's ability to analyze and solve problems.

\section{Comprehensive Evaluation System}

The comprehensive evaluation system is designed as follows: 
Table 1 Comprehensive evaluation index

\begin{tabular}{|c|c|c|c|c|c|}
\hline $\begin{array}{c}\text { Integrative } \\
\text { achievement }\end{array}$ & \multicolumn{2}{|c|}{ Usual achievement [40\%] } & \multicolumn{2}{|c|}{$\begin{array}{c}\text { Final exam } \\
{[60 \%]}\end{array}$} \\
\hline Constitution & $\begin{array}{c}\text { Extracurricular } \\
\text { practice }\end{array}$ & $\begin{array}{c}\text { Class } \\
\text { discussion }\end{array}$ & homework & $\begin{array}{c}\text { Objective } \\
\text { questions }\end{array}$ & $\begin{array}{c}\text { Subjective } \\
\text { questions }\end{array}$ \\
\hline ratio & $10 \%$ & $15 \%$ & $15 \%$ & $36 \%$ & $24 \%$ \\
\hline
\end{tabular}

College Ideological and political theory course should integrate into the socialist core value system education curriculum content, through the ideological and political theory course unique function, the socialist core value system plays a leading role in the ideological and political education in universities.

\section{Conclusions}

It is a systematic project to assimilate the socialist core value system into the ideological and political theory course in Colleges and universities. As teachers of Ideological and political theory education in Colleges and universities, it's necessary to explore effective ways of education of socialist core value system, the establishment of long-term mechanism of education of socialist core value system, which enhances the comprehensive quality of College students.

\section{Acknowledgements}

Qujing Normal University Project (2013Y009)

\section{References}

[1] L.J. Feng, The Inner Logic of Cultivating the Socialist Core Values, Journal of Beijing Normal University(Social Sciences) (2013) No.2, p.13-18.

[2] Information on http://news.gmw.cn

[3] J.P. Xi, Speech at the Symposium on teachers and students at Peking University (2014)

[4] J.T. Hu, Unswervingly follow the road of socialism with Chinese characteristics and strive to build a moderately prosperous society in all respects (2012)

[5] Information on http://www.aisixiang.com/data/41227.html

[6] J.T. Hu, Creating new achievements in the new century (1998)

[7] J.T. Hu, Speech at the National Conference on strengthening and improving college students' Ideological and Political Education (2005)

[8] R.W. Liu, Governing the country according to law and upholding the people's democratic dictatorship, Red Flag Manuscript, (2014) No. 19, p.29-30.

[9] Anonymous, Decision of the CPC Central Committee on deepening the reform of the cultural system and promoting the development and prosperity of socialist culture, People's Publishing Press, Beijing, 2011, pp. 22-32.

[10]Information on http://zhujingjie.fyfz.cn/b/827948 